Nota dos editores / Editors' Note

\section{Bibliometria e visibilidade da Psiquiatria brasileira}

De uma maneira não planejada, porém não menos importante, o presente número da Revista Brasileira de Psiquiatria reúne um rol variado de contribuições que tocam a questão da visibilidade e o peso da contribuição da psiquiatria brasileira. Já nos editoriais destaca-se a contribuição de Dainesi e Pietrobon que, de forma didática, esclarecem a necessidade da adoção de índices bibliométricos que avaliem o peso da contribuição científica atribuída a um artigo, a autores, ou grupos de pesquisa. Tal análise é crucial na decisão da atribuição de recursos a fim de que eles possam ser aproveitados de forma mais eficiente. Contudo, os próprios autores advertem que é preciso conhecer as limitações desses mesmos índices para evitar sua manipulação. Um excelente exemplo nos é providenciado pelo artigo especial de Kieling e Gonçalves, que analisa o aumento de visibilidade da Revista Brasileira de Psiquiatria após sua indexação nas duas principais bases de dados em medicina: ISI e PubMed/MEDLINE.

O artigo é também uma ótima oportunidade para se entender o que significa o fator de impacto e qual sua importância para uma revista que, como a nossa, está localizada fora do eixo Europa-América do Norte. Precisamos de uma publicação sólida, cuja qualidade possa ser reconhecida por parâmetros locais e internacionais simultaneamente, que possa abrigar em seu conteúdo artigos que posicionem a produção local (Brasil e América Latina) em relação ao mundo e que ao mesmo tempo seja sensível às variações próprias de nossa cultura e geografia.

No artigo de Razzouk et al. fica claro que em nosso pólo geográfico e cultural dois países têm se destacado neste esforço: México e Brasil. Ainda assim, nossa produção é modesta e o percurso para ampliá-la é cravejado de obstáculos e conflitos de difícil conciliação. Na seção de cartas temos outro excelente exemplo. Em resposta à carta de Sougey, criticando a omissão de autores brasileiros no suplemento sobre estresse pós-traumático, Kapczinski toca em questões delicadas e pertinentes muito do que se produz em nosso país fica retido em teses e dissertações não publicadas, ou à sombra em periódicos de pequena projeção por não estarem indexados em bases de dados com suficiente penetração na comunidade científica.

Porém, é fato que, atraídos pelo brilho da produção internacional, tendemos a negligenciar a produção local. A questão é: por quê? Dentre motivos variados, retornamos a um que é óbvio e objetivo. Quando o pesquisador nacional vai a uma base de dados internacional, ele precisa se re-encontrar lá com a produção local. Não há escapatória, se quisermos saber mais sobre nós mesmos precisamos nos projetar no exterior. Isto inclui, por exemplo, a decisão de manter os artigos originais da RBP em inglês para garantir sua visibilidade internacional, ao mesmo tempo em que asseguramos ao leitor local suplementos, revisões e atualizações em português para garantir uma educação médica continuada ampla e de alto nível.

Enfim, além da habitual seleção de artigos de qualidade, o presente número oferece a todos nós uma oportunidade de refletir sobre os objetivos de uma revista de psiquiatria brasileira e latino-americana, como alcançá-los e como nos certificar por bons parâmetros, que estamos de fato mais próximos dos nossos ideais.

Hermano Tavares Euripedes C Miguel Jair de Jesus Mari Luis Augusto Rohde Marcos T Mercadante Rodrigo Affonseca Bressan

\section{Bibliometrics and visibility of the Brazilian Psychiatry}

The current issue of the Revista Brasileira de Psiquiatria brings on a non-planned but not less important way a varied set of contributions approaching the visibility and the relevance of the Brazilian psychiatry. Beginning with the editorials, it is important to highlight the text by Dainesi and Pietrobon that, in a didactic manner, explains the need of using bibliometric indices to assess the scientific relevance of articles, authors or research groups. This analysis is fundamental for deciding about funds allocation so that such resources can be spent as efficiently as possible. However, the authors themselves warn about the need of knowing the limitations of such indices in order to avoid biases. An excellent example is provided by the special article by Kieling and Gonçalves who analyze the increasing visibility of the Revista Brasileira de Psiquiatria after it was indexed in the main medical databases: ISI and PubMed/MEDLINE.

The article is also a great opportunity for understanding the meaning of the impact factor and its importance to a journal that, like ours, is published outside Europe and North America. We need a solid journal, whose quality can be simultaneously acknowledged through local and international parameters, including articles that place the local scientific production (Brazilian and Latin American) in regard to the world and that, at the same time, be sensitive to the peculiar characteristics of our culture and geography.

The article by Razzouk et al. evidences that there are two countries showing outstanding results in our geographical and cultural region: Mexico and Brazil. Even though, our scientific production is modest and the path to increase it is full of obstacles and conflicts that are difficult to conciliate. In the letters section, there is another excellent example. In a reply to the letter by Sougey criticizing the lack of Brazilian authors in the supplement about posttraumatic stress, Kapczinski discusses delicate and significant issues - a great portion of the Brazilian scientific production remains restricted to unpublished thesis and dissertations or hidden in journals of little visibility due to the fact that they are not indexed in databases widely disseminated in the scientific community.

However, it is true that we tend to neglect the local production because we are attracted to the brightness of the international production. The core question we have to answer is "why does it happen?" Among several reasons, we can mention one that is obvious and objective. When a national researcher searches an international database, he or she needs to meet again with the local production in such a database. There is no escape; if we want to know more about ourselves we need to show ourselves abroad. That includes, for instance, the decision of keeping the original articles of the Revista Brasileira de Psiquiatria in English in order to assure their international visibility, while we provide the local reader with supplements, literature reviews and updates in Portuguese guaranteeing a continuous medical education that has high quality and comprehensiveness.

In other words, besides the usual selection of high quality articles, this current issue provides us with an opportunity to think about the goals of a psychiatry journal from Brazil and Latin America, how to reach them and how to make sure through valid parameters that we are indeed getting closer to our ideals.

Hermano Tavares Euripedes C Miguel Jair de Jesus Mari Luis Augusto Rohde Marcos T Mercadante Rodrigo Affonseca Bressan 